\section{Prof. A. F. Dixon}

MANy readers of NaTuRE will feel a personal sorrow at the loss which Trinity College, Dublin, has sustained by the death on January 15 of Prof. Andrew Francis Dixon, University professor of anatomy since 1903, and dean of the Faculty of Physic. If the life and work of any man merits appreciation in these pages, that man is Prof. Dixon, for he was above all a lover of Nature. His great academic and administrative qualities have already been referred to in the Press, and it is rather of his personal side that I wish to write.

Francis Dixon was a great man, and his life sets an example which we would all do well to follow. To make use of an expression of his own, he was "a whale for work" ; his generosity must be known to many ; his complete unselfishness was evident in all he did, and his kindliness, humour, simplicity and oldfashioned courtesy will long be remembered by all who knew him. Many will remember the tall, upright figure, with white hair, that used to be so red, and the wonderfully blue eyes; and all who ever met him will recall with joy the great paw thrust out in friendly greeting, the quiet soft voice and kindly grin, and the feeling of personal interest that he gave to anyone with whom he was conversing.

Dixon was beloved by all : the poor people round his country home who never turned to him in vain; the staff of his department, of whom he was so thoughtful and appreciative of any little thing they did for him, and whom he was always so anxious to save from any worry or responsibility which he thought should have been his own; his colleagues in the University, who so often sought his advice and who so greatly valued his opinion; his fellow anatomists in Great Britain and abroad, by all of whom he was loved, respected and admired; the staff of the Dublin Zoo, which he loved so well and to which he devoted so much of his untiring energy ; and the generations of students, whose interests and welfare were the main objects of his life. His energy and vitality were astonishing, and his interests were so wide, that no one ever talked with Dixon without feeling that they had learned something from him.

Dixon's tastes were simple. He loved the countryside; the country people; all animals; his bees, though he often got badly stung; indeed all the works of Nature, the sunrise across the Irish Sea, the star-light nights, the night-jars, the cross-bills and all the birds around his country home at Kilternan, in the Dublin mountains. He loved the earth and the sea and all that therein is; the rocks and their fossils; the mountain streams in which he liked to lie and bask in the sun with his pipe in his mouth at full blast; all the creatures of the sea; he would kneel for hours on a board on the sands at Malahide, looking for the anemone, Halcampa; he liked to go out with a trawl in Dalkey Sound and bring up all sorts of beautiful creatures.
The hospitality and kindness of the House of Dixon will be long remembered by many a lonely student who came to Trinity from foreign parts ; the tea table on Sunday, at Kilternan, was always set for seven or eight, but if a dozen or more arrived unexpectedly it made no difference; there was a kind welcome for all, and Mrs. Dixon seemed to have an inexhaustible larder. There were always jobs to be done at Kilternan for those who liked, and if not, there was a bed and a book on the verandah, looking out on the beautiful Dublin mountains, where Dixon encouraged his visitors to "press their coat" on Sunday afternoon.

"Andy Frank", as he was always known to his students, was the life and soul of the Medical School in Trinity College, and I fear that we shall not see his like again.

C. M. West.

\section{Mr. A. M. McBain}

WE regret to record the tragic death on January 10 at the age of thirty-four years of Alan McBain, assistant in potato virus research at the Scottish Plant Breeding Station. His published work dealt with the physiological side of the subject, and had he lived he would have made a permanent name for himself in this kind of investigation. McBain was by training and inclination a particularly able physiological chemist, and it was a pleasure to watch him at work in a laboratory. $\mathrm{He}$ was never at a loss when confronted with some practical difficulty, and he had few equals when it came to a question of erecting or improvising new apparatus.

MoBain's first investigation dealt with a comparative examination of the synthesis of carbohydrates in healthy and 'leaf-roll' potatoes. This line of investigation he later extended to the virus complex, crinkle. Afterwards he made an examination of the nitrogen metabolism of healthy and 'leaf-roll' potatoes; but for a variety of reasons he was unable to complete a similar examination of the nitrogen relations of healthy and crinkle plants, although such results as were obtained were of considerable interest.

Apart from his scientific work, McBain had a large number of interests, and his name will long be remembered for his activities in connexion with various unemployment aid centres in Edinburgh, Glasgow and elsewhere. No one could have had a more pleasant colleague, and he will be sadly mourned by his many friends.

E. B. W.

WE regret to announce the following deaths :

Prof. J. H. Ashworth, F.R.S., professor of natural history in the University of Edinburgh, on February 4, aged sixty-one years.

Dr. Gilbert Brooke, formerly director of the Far Eastern Health Bureau, Singapore, known for his work in public health especially. in connexion with malaria, aged sixty-two years.

Dr. Alfred C. Woolner, C.I.E., Vice-Chancellor of the University of the Punjab, Lahore, on January 7, aged fifty-seven years. 